\title{
Attributes of Eurasian Green Woodpecker (Picus viridis) nest cavities in Hungary
}

\section{Gerard GORMAN}

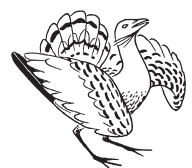

Received: September 28, 2020 - Revised: October 2, 2020 - Accepted: October 05, 2020

Gorman, G. 2020. Attributes of Eurasian Green Woodpecker (Picus viridis) nest cavities in Hungary. - Ornis Hungarica 28(2): 204-211. DOI: 10.2478/orhu-2020-0025

\begin{abstract}
Thirty-three nest cavities of Green Woodpeckers (Picus viridis) in Hungary were documented over a period of 15 years (2006-2020). Thirteen different tree species were used. All documented cavities were in the main trunks of trees. The mean cavity height was $5.6 \mathrm{~m}$ and $1.5 \mathrm{~m}$ standard deviation and ranged from 2 to $9 \mathrm{~m}$. Tree trunk diameters ranged between $36-55 \mathrm{~cm}$ with a mean of $43.1 \mathrm{~cm}$ and $4.2 \mathrm{~cm}$ standard deviation. A southerly orientation of cavity entrances prevailed with a mean direction of $187^{\circ}$ clockwise from north. The results suggest that cavity-entrance orientation was non-random.
\end{abstract}

Keywords: woodpecker nesting cavity, cavity location, cavity height, cavity entrance orientation

Összefoglalás Összesen 33 magyarországi zöld küllö (Picus viridis) odúról készült dokumentáció 15 év alatt, 2006-2020-ig. A madarak minden vizsgált esetben a fák törzsébe vájták az odúkat, ehhez összesen 13 különböző fafajt választottak. A röpnyílás átlagos magassága a talajtól számítva 5,6 m volt 1,5 m-es szórással, 2-9 m-es kiterjedéssel. A mellmagassági törzsátmérö $36-55 \mathrm{~cm}$ közé esett 43,1 cm-es átlaggal és 4,2 cm-es szórással. Az odúk délies tájolásúak voltak (átlagban $187^{\circ}$, északról számolva, az óramutató járása szerint). Az eredmények alapján megállapítható, hogy a röpnyílások tájolása nem véletlenszerú.

Kulcsszavak: harkály költőodú, az odú helye, odúmagasság, röpnyílás tájolása

Independent Researcher, Hungarian Woodpecker Working Group, c/o MME BirdLife Hungary, Budapest, Hungary,e-mail: picidae.gerard@gmail.com

\section{Introduction}

The global distribution of Green Woodpecker (Picus viridis) falls almost entirely within the Western Palearctic region with approximately $95 \%$ of its total population considered to be within Europe (BirdLife 2020). The species is found from Britain in the west to Russia and Turkmenistan in the east, and from Norway, Sweden and Estonia in the north to Italy, the Balkans and Turkey in the south, and in the southeast to Iran and Iraq. It is absent from Finland and islands such as Gotland, Corsica, Sardinia, Malta, Crete, Cyprus and Ireland, although vagrant individuals have been observed on some of these islands. The species is resident, non-migratory and typically highly sedentary, although post-breeding dispersal of juveniles takes place (Glutz \& Bauer 1994, Winkler et al. 1995, Gorman 2004, 2020).

The Green Woodpecker is polytypic, with three subspecies generally recognised: viridis in Britain, southern Scandinavia and continental Europe (including Hungary) and western Russia; karelini in Italy, the southern Balkans, the Caucasus and to Turkmenistan; and 
innominatus, which occurs solely in the Zagros Mountains in Iran and Iraq (del Hoyo \& Collar 2014, Gorman 2014, 2020).

The species inhabits a diversity of wooded habitats across this range, which covers three eco-climatic regions: the temperate, Mediterranean and the boreal zones. Typical breeding habitats occupied include open forests and woodlands, riparian woods, parkland, orchards and large gardens. Green Woodpeckers mostly frequent deciduous trees, but in some areas mixed deciduous-coniferous woodlands are used. Dense forests are avoided. In all areas, adjacent grasslands, where birds can forage for terrestrial ants, are essential (Alder \& Marsden 2010). In Europe, Green Woodpeckers occur in both lowlands and uplands, to around 2,000 m, only occasionally higher (Gorman 2020).

Although there have been declines locally, often owing to grassland and/or wooded habitat degradation, the overall trends for this species are positive and it is not considered to be threatened. In the IUCN Red List of Threatened Species, Green Woodpecker is classified as Least Concern (BirdLife 2016).

Green Woodpecker nest cavity characteristics, particularly orientation of entrance holes, have not been widely studied. Existing data have generally been published as part of broader studies on other woodpecker and cavity-nesting bird species (Aulén 1988, Hågvar et al. 1989, Blume 1996, Kosiński \& Kempa 2007, Zhou et al. 2012). Cavity orientation in this species had not been previously studied in Hungary and the aim of this work was to gather data to improve the knowledge and understanding of its habitat requirements.

\section{Methods}

This study was restricted to nest cavities that were used by Green Woodpeckers in Hungary. The study area covered six hill ranges across the north of the country. Namely, from west to east, the Gerecse, Buda, Pilis, Bükk, Aggtelek and Zemplén. These low ranges (the highest points in each are all below $1,000 \mathrm{~m}$ above sea-level) are characterized by deciduous forests and woodlands. The research was conducted between 2006 and 2020 . The search for cavities was carried out from March to May in each year as this is the period when Green Woodpeckers mostly excavate and occupy them, although cavities are sometimes excavated at other times of the year (Gorman 2011). Sites where Green Woodpeckers had been observed previously were investigated and cavities found by observing the behaviour of birds, such as individuals persistently calling, indulging in courtship behaviour or carrying food for nestlings, and by looking for signs of excavation, such as fresh woodchips below trees. Trees with cavities excavated in previous years were also checked. A total of thirty-three (33) cavities were documented. The study did not deal with breeding success, rather the five main aims were: (1) to determine tree species used; (2) to document cavity locations, whether on trunks or limbs; (3) to measure the height of cavity entrances above ground level; (4) to measure the trunk diameters at breast height (DBH) of trees with cavities; (5) to document the orientation of cavity entrances. Cavity height was estimated using simple trigonometry. The diameter of cavity trees was calculated by means of the standard method of DBH, with measurements taken using calipers 
at $1.3 \mathrm{~m}$ above the ground from the base of the trunk. Cavity orientation was calculated with a compass, using sixteen standard points (N, NNE, NE, ENE, etc.). The randomness of orientation was assessed using a Rayleigh test of uniformity (Pewsey et al. 2013) as implemented in the package 'circular' in R (Lund \& Agostinelli 2011, R Development Core Team 2015).

\section{Results and discussion}

Some attributes of thirty-three nest cavities and their locations were documented. All cavity trees were in open wooded areas dominated by broadleaved trees. All cavities documented were newly excavated: none were from previous years that were being reused. New cavities can be recognized by their entrances having clean edges with no renewed tree growth, and light-coloured wood (Gorman 1995). Most cavity entrances were circular in shape, although four were vertically oval and one horizontally oval in shape. Cavity entrance dimensions were not measured.

\section{Trees used}

Across their range Green Woodpeckers do not seem to show any significant preference for particular tree species, rather they are only associated with specific trees locally. The openness of a woodland or forest and availability of ant prey is probably more important for this species (Spitznagel 1990, Rolstad et al. 2000, Riemer et al. 2010). The variety of trees found across the range of the species varies significantly. Almost any tree is used for nesting providing the bole is large enough to house a cavity. An area of soft wood, usual due to fungal decay, facilitates easier excavation. Nevertheless, broadleaved trees are generally selected over coniferous (Glue \& Boswell 1994). In this study, nest cavities were found in thirteen different tree species (number of times used in brackets): common alder Alnus glutinosa (1), ash Fraxinus excelsior (5), beech Fagus sylvatica (3), elm Ulmus minor (2), hornbeam Carpinus betulus (2), horse chestnut Aesculus hippocastanum (1), oaks Quercus spp. (5), poplar Populus spp. (4), plane Platanus spp. (1), small-leaved lime Tilia cordata (3), sycamore Acer pseudoplatanus (1), walnut Juglans regia (2) and willow Salix spp. (3). All cavities were in broadleaved trees with none in coniferous species. There was no clear dominance by one tree species (see Table 1). While no tree species dominated the sample, this was not tested for selection by Green Woodpeckers due to lack of data on relative tree species availability from within the study area.

\section{Cavity location}

All cavities found were placed in foliage-free sections on the main trunk of trees and were below canopy level, with a clear flyway to the entrance. No cavities were found in branches. All were in living trees, but in parts with soft and/or deadwood and with the presence of fungi evident. 
Table 1. Summary of cavities used by Green Woodpeckers

1. táblázat A zöld küllők által használt odúk adatai

\begin{tabular}{|c|c|c|c|c|c|}
\hline Year & Location & Tree species & $\begin{array}{c}\text { Height above } \\
\text { ground } \\
\text { (approx. metres) }\end{array}$ & $\begin{array}{l}\text { Tree-trunk } \\
\text { width (DBH) } \\
\text { in } \mathrm{cm}\end{array}$ & $\begin{array}{c}\text { Cavity- } \\
\text { entrance } \\
\text { orientation }\end{array}$ \\
\hline 2006 & Pilis Hills & Ash & 7 & 40 & SW \\
\hline 2006 & Zemplén Hills & Oak spp. & 5.5 & 46 & SSW \\
\hline 2007 & Bükk Hills & Elm & 6 & 38 & SE \\
\hline 2008 & Buda Hills & Poplar spp. & 6.5 & 40 & $S$ \\
\hline 2008 & Pilis Hills & Oak spp. & 5 & 45 & NE \\
\hline 2008 & Buda Hills & Ash & 7 & 44 & SW \\
\hline 2009 & Pilis Hills & Oak spp. & 4.5 & 42 & SE \\
\hline 2009 & Bükk Hills & Willow spp. & 6 & 42 & NW \\
\hline 2010 & Buda Hills & Poplar spp. & 5 & 40 & $S$ \\
\hline 2011 & Zemplén Hills & Walnut & 3 & 38 & SE \\
\hline 2011 & Pilis Hills & Beech & 9 & 55 & SSE \\
\hline 2012 & Buda Hills & Oak spp. & 5 & 48 & WSW \\
\hline 2012 & Bükk Hills & Hornbeam & 6.5 & 40 & WSW \\
\hline 2012 & Bükk Hills & Ash & 6 & 38 & SSW \\
\hline 2013 & Gerecse Hills & Willow spp. & 5 & 36 & $S$ \\
\hline 2013 & Zemplén Hills & Beech & 6 & 45 & W \\
\hline 2013 & Pilis Hills & Sycamore & 5 & 44 & SSE \\
\hline 2014 & Aggtelek & Ash & 5 & 40 & $\mathrm{E}$ \\
\hline 2014 & Bükk Hills & Plane & 4 & 42 & SW \\
\hline 2015 & Zemplén Hills & Lime & 7.5 & 50 & S \\
\hline 2015 & Buda Hills & Elm & 5.5 & 42 & WSW \\
\hline 2015 & Pilis Hills & Beech & 8 & 45 & ESE \\
\hline 2016 & Aggtelek & Hornbeam & 3.5 & 38 & SW \\
\hline 2016 & Zemplén Hills & Oak spp. & 7 & 50 & SE \\
\hline 2016 & Gerecse Hills & Poplar sp. & 4 & 44 & SW \\
\hline 2017 & Zemplén Hills & Willow spp. & 3 & 42 & SE \\
\hline 2017 & Bükk Hills & Lime & 7 & 50 & $S$ \\
\hline 2017 & Zemplén Hills & Walnut & 2 & 45 & W \\
\hline 2018 & Bükk Hills & Common Alder & 7 & 44 & ESE \\
\hline 2018 & Zemplén Hills & Ash & 7 & 45 & SW \\
\hline 2019 & Gerecse Hills & Poplar spp. & 6.5 & 38 & $E$ \\
\hline 2019 & Buda Hills & Horse Chestnut & 5 & 44 & $S$ \\
\hline 2020 & Bükk Hills & Lime & 6 & 45 & SW \\
\hline
\end{tabular}




\section{Cavity height}

Entrance-hole heights of Green Woodpeckers can vary considerably, from as low as $1 \mathrm{~m}$ above ground level to as high as $9 \mathrm{~m}$, but most are located between 2-5 m (Glue \& Boswell 1994, Glutz \& Bauer 1994, Solti 2010). In this study, there was also significant variation in the heights of cavities above ground level. The highest cavity entrance was located at $9 \mathrm{~m}$, the lowest $2 \mathrm{~m}$. The most frequently documented height was $5 \mathrm{~m}$ (7 cavities: $21.21 \%)$ with the mean of $5.6 \mathrm{~m}$ and standard deviation $1.5 \mathrm{~m}$.

\section{Tree trunk width}

The widest diameter $(\mathrm{DBH})$ of a cavity tree was $55 \mathrm{~cm}$ and the narrowest $36 \mathrm{~cm}$. The most frequently documented diameter was $45 \mathrm{~cm}$ (6 cavities: $18.18 \%)$, with a mean of $43.1 \mathrm{~cm}$ and standard deviation of $4.2 \mathrm{~cm}$.

\section{Cavity entrance orientation}

Of the thirty-three cavities, twenty-two $(66.67 \%)$ faced southwards (SE, SSE, S, SSW, SW). The most frequent alignment was SW with seven $(21.21 \%)$ cavities. Four cavities were orientated towards the east (E, ESE), five westwards (WSW, W, WNW), one cavity was orientated towards the NW and one to the NE. The cavity orientation was non-random and significantly biased toward the south (Rayleigh test $\mathrm{r}=0.57, \mathrm{p}<0.001$ ) with a mean direction of 187 degrees clockwise from north (Figure 1).

\section{Conclusions}

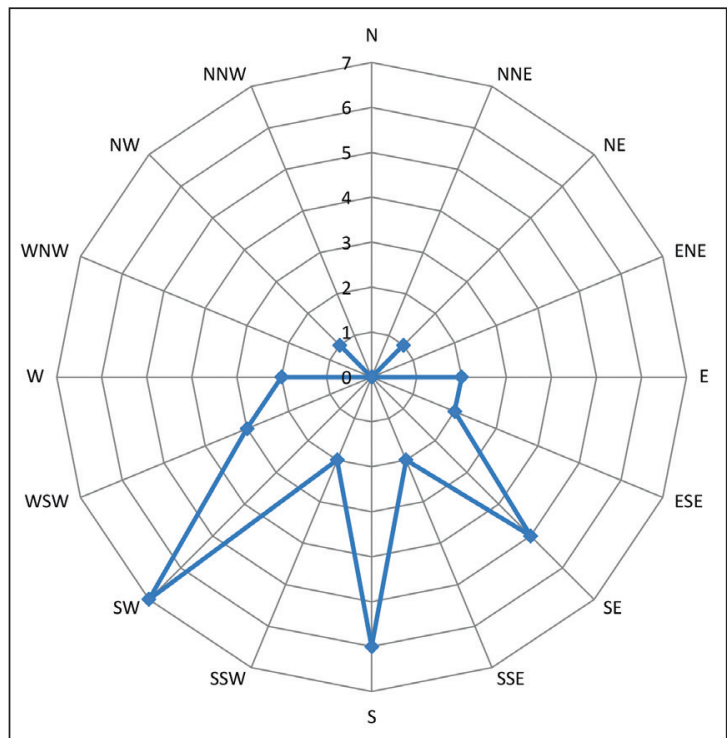

Figure 1. Orientation of Green Woodpecker cavity entrances as frequencies of cardinal points

1. ábra A zöld küllő költőodúk tájolása 16 alégtáj szerint

This paper summarizes some attributes of thirty-three nest cavities of Green Woodpeckers in Hungary over a period of fifteen years. Cavities were found in thirteen different tree species, but there was no evidence that these species held any specific significance for Green Woodpeckers.

As is the case with most picids when selecting a cavity location, it is likely that ease of excavation seemed to be more important than any link to a specific tree species. Most woodpeckers, Green Woodpecker included, invest a substantial amount of time and energy in excavating cavities and, despite being morphologically adapted to excavate timber, 
it is known that they tend to select parts of trees where it is relatively easy for them to do so with dead or dying sections usually chosen. The hardness of the interior wood of trees is considered to be a key element in cavity site selection (Kosiński \& Winiecki 2004, Kosiński et al. 2006, Kosiński \& Kempa 2007, Matsuoka 2010, Lorenz et al. 2015). Dying or living trees with weak and soft areas resulting from decay, due to fungal or insect infestation, or wounds from lightning strikes, strong winds, frost and the like, present better opportunities for cavity excavation than those that are healthy and sound. Studies of two species that are often sympatric with Green Woodpecker in continental Europe, Black Woodpecker Dryocopus martius (Zahner et al. 2012, Puverel et al. 2019) and Grey-headed Woodpecker Picus canus (Gorman 2019) have indicated that trees affected with fungal rot are regularly chosen for cavities. Although it was not possible to verify the presence or extent of decay in every cavity tree in the present study, most tended to be more fungus-afflicted than surrounding trees. At least thirty (90.91\%) of the thirty-three showed obvious signs of rot in the area of trunk that housed the cavity. Nesting trees were also always amongst the biggest trees in the area, with large enough boles to house a cavity. It was suspected that the location, condition and relative size of each tree, rather than its species, resulted in it being selected for a nest cavity.

The openness of nesting habitat and accessibility of prey, particularly terrestrial ants, is known to be critical for Green Woodpeckers (Spitznagel 1990, Rolstad et al. 2000, Riemer et al. 2010). The extent to which the surrounding vegetation influenced the selection of cavity trees at the sites documented was not examined in detail, however, at each locations, the surrounding habitat clearly offered suitable foraging opportunities, in the form of various short-grassed habitats.

A frequent question that researchers have sought to answer is whether the entrance orientation of woodpecker cavities is determined by compass direction. Studies globally have yielded contrasting conclusions. One evaluation of cavity-entrance orientation from eighty populations of twenty-three species of woodpecker throughout the Northern Hemisphere concluded that the orientation was influenced by regional climatic forces and was typically non-random (Landler et al. 2014). In the present study of Green Woodpecker cavities, a southerly alignment and orientation of entrances prevailed, and the results suggest that cavity-entrance orientation was non-random. A study, also conducted in Hungary, of cavities of a close relative, the Grey-headed Woodpecker, produced similar results (Gorman 2019).

The reasons for this choice of direction are unclear with a number of factors likely to be implicated. Notably, prevailing wind direction may be involved: in Hungary it is from a north-westerly direction (Hungarian Meteorological Service, undated). Temperature, average rainfall levels and degree of sunlight may also influence the orientation of cavities; those facing southwards and eastwards receive more sun, hence illumination and warmth, in the morning hours. The higher number of entrances facing southwards suggests that early-morning warming is preferred. However, a compromise may exist. Local conditions and circumstances may result in some factors outweighing and overriding others. For example, the southward-facing sides of tree trunks may not necessarily catch the most sun and warmth owing to the surrounding environment: other trees, bushes or 
buildings may all result in shade. Furthermore, woodpeckers, when making cavities, may disregard compass direction in order to conserve excavation energy output. Cavities facing away from the south may be created because to do so requires less effort. A section of tree where a cavity can be more easily excavated, because the wood is softest, may be selected, although it may not be ideal in terms of entrance orientation.

\section{Acknowledgements}

The author wishes to thank Danny Alder and Ken Smith for their helpful comments and assistance with statistics, and also two anonymous referees for their constructive remarks.

\section{References}

Alder, D. \& Marsden, S. 2010. Characteristics of feeding-site selection by breeding Green Woodpeckers Picus viridis in a UK agricultural landscape. - Bird Study 57(1): 100-107. DOI: 10.1080/00063650903437511

Aulén, G. 1988. Ecology and distribution history of the White-backed Woodpecker Dendrocopos leucotos in Sweden. - PhD Thesis, SLU Uppsala, Sweden, Report 14.

BirdLife International 2016. Picus viridis. The IUCN Red List of Threatened Species 2016. - Accessed: 01/09/2020.

BirdLife International 2020. Species factsheet: Picus viridis. - www.birdlife.org. Accessed: 01/09/2020.

Blume, D. 1996. Schwarzspecht, Grauspecht, Grünspecht [Black, Grey \& Green Woodpeckers]. - Neue Brehm-Bücherei Heft 300. 5. überarb. Auflage. Westarp Wissenschaften, Magdeburg (in German)

del Hoyo, J. \& Collar, N. J. 2014. HBW and BirdLife International Illustrated Checklist of the Birds of the World. Vol. 1. - Lynx Edicions, Barcelona

Glue, D. E. \& Boswell, T. 1994. Comparative nesting ecology of the three British breeding woodpeckers. British Birds 87: 253-269.

Glutz von Blotzheim, U. N. \& Bauer, K. M. (eds.) 1994. Handbuch der Vogel Mitteleuropas. Band 9. Columbiformes-Piciformes [Handbook of the Birds of Central Europe, Vol. 9.]. - AULA-Verlag Gmbh, Wiesbaden (in German)

Gorman, G. 1995. Identifying the presence of woodpecker (Picidae) species on the basis of their holes and signs. - Aquila 102: 61-67.

Gorman, G. 2004. Woodpeckers of Europe. A study of the European Picidae. - Coleman, Chalfont St. Peter, UK.

Gorman, G. 2011. Green Woodpecker excavating a cavity in autumn. - British Birds 104: 276.

Gorman, G. 2014. Woodpeckers of the World: the complete guide. - Helm, London, UK.

Gorman, G. 2019. Characteristics of Grey-headed Woodpecker (Picus canus) cavities in Hungary. - Aquila $126: 33-39$.

Gorman, G. 2020. The Green Woodpecker - A monograph on Picus viridis. - Picus Press, UK.

Hågvar, S., Hågvar, G., Hailman, E. D. \& Hailman, J. P. 1989. The direction of the hole in Norwegian woodpecker nests. - Fauna Norvegica Series C 12: 106-107.

Hungarian Meteorological Service (undated): Wind conditions of Hungary. - Accessed: https://www.met.hu/ en/eghajlat/magyarorszag_eghajlata/altalanos_eghajlati_jellemzes/szel/ (01/09/2020)

Kosiński, Z. \& Winiecki, A. 2004. Nest-site selection and niche partitioning among the Great Spotted Woodpecker Dendrocopos major and Middle Spotted Woodpecker Dendrocopos medius in riverine forest of Central Europe. - Ornis Fennica 81(4): 145-156.

Kosiński, Z., Ksit, P. \& Winiecki, A. 2006. Nest site of Great Spotted Woodpeckers Dendrocopos major and Middle Spotted Woodpeckers Dendrocopos medius in near-natural and managed riverine forests. - Acta Ornithologica 41(1): 21-32. DOI: 10.3161/000164506777834624

Kosiński, Z. \& Kempa, M. 2007. Density, distribution and nest-sites of woodpeckers Picidae, in a managed forest of Western Poland. - Polish Journal of Ecology 55(3): 519-533. 
Landler, L., Jusino, M. A., Skelton, J. \& Walters, J. R. 2014. Global trends in woodpecker cavity entrance orientation: latitudinal and continental effects suggest regional climate influence. - Acta Ornithologica 49(2): 257-266. DOI: $10.3161 / 173484714$ X687145

Lorenz, T. J., Vierling, K. T., Johnson, T. R. \& Fischer, P. C. 2015. The role of wood hardness in limiting nest site selection in avian cavity excavators. - Ecological Applications 25(4): 1016-1033. DOI: 10.1890/14-1042.1

Lund, U. \& Agostinelli, C. 2011. Package 'circular': circular statistics. - R package version 0.4-3.

Matsuoka, S. 2010. Great Spotted Woodpeckers Dendrocopos major detect variation in wood hardness before excavating nest holes. - Ornithological Science 9(1): 67-74. DOI: 10.2326/osj.9.67

Pewsey, A., Neuhauser, M. \& Ruxton, G. D. 2013. Circular Statistics in R. - OUP, Oxford

Puverel, C., Abourachid, A., Böhmer, C., Leban, J-M., Svoboda, M. \& Paillet, Y. 2019. This is my spot: what are the characteristics of the trees excavated by the Black Woodpecker? A case study in two managed French forests. - Forest Ecology and Management 453: 117621. DOI: 10.1016/j.foreco.2019.117621

R Development Core Team 2015. A language and environment for statistical computing. - R Foundation for Statistical Computing, Vienna, Austria

Riemer, S., Schulze, C. H. \& Frank, G. 2010. Population density and habitat use of the Green Woodpecker Picus viridis in Donau-Auen National Park (Lower Austria). - Vogelwarte 48(3): 275-282. (in German with English Summary)

Rolstad, J., Løken, B. \& Rolstad, E. 2000. Habitat selection as a hierarchical spatial process: the Green Woodpecker at the northern edge of its distribution range. - Oecologia 124(1): 116-129. DOI: 10.1007/ s004420050031

Solti, B. 2010. A Mátra Múzeum madártani gyüjteménye III. Németh Márton tojásgyüjtemény [The ornithological collection of the Mátra Museum III Márton Németh's egg collection]. - Folia Historico-naturalia Musei Matraensis Suppl. 5: 1-275. (in Hungarian)

Spitznagel, A. 1990. The influence of forest management on woodpecker density and habitat use in floodplain forests of the Upper Rhine Valley. - In: Carlson, A. \& Aulén, G. (eds.) Conservation and Management of Woodpecker Populations. - Swedish University of Agricultural Sciences, Dept of Wildlife Ecology, Report 17. Uppsala

Winkler, H., Christie, D. A. \& Nurney, D. 1995. Woodpeckers: A guide to the woodpeckers, piculets and wrynecks of the World. - Pica Press, Robertsbridge, UK.

Zahner, V., Sikora, L. \& Pasinelli, G. 2012. Heart rot as a key factor for cavity tree selection in the Black Woodpecker. - Forest Ecology and Management 271: 98-103. DOI: 10.1016/j.foreco.2012.01.041

Zhou, C., Zhou, D., Kong, X. \& Deng, W. 2012. Differentiating nest sites characteristics of four sympatric cavity-nesting birds. - Biodiversity Science 20(6): 716-724. DOI: 10.3724/SP.J.1003.2012.09068

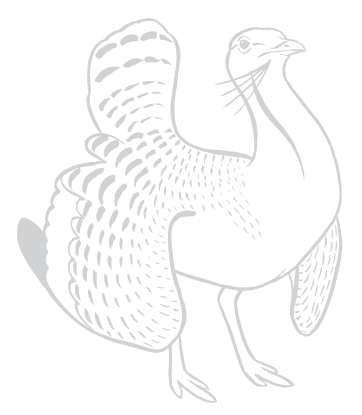

